\title{
Regeneration of Babaco (Carica pentagona) from Ovular Callus
}

\author{
R. Vega de Rojas ${ }^{1}$ and S.L. Kitto ${ }^{2}$ \\ Delaware Agricultural Experiment Station, Department of Plant Science, College of Agricultural \\ Sciences, University of Delaware, Newark DE 19717-1303
}

Additional index words. somatic embryogenesis

\begin{abstract}
Ovules of babaco [ Carica pentagona (Heilborn) Badillo], 23 to 140 days old, were cultured to initiate regenerative callus. Callus developed from the integuments and possibly from the nucellus. Ovules of greater length and age produced more calli on White's medium or medium with half-strength MS salts than on full-strength MS. Ovules >60 days old that were chilled for 24 hours produced significantly more callus than fresh ovules <60 days old. Ovular calli of summer and fall fruits (73 to 90 days old) grown at $23 \pm 2 \mathrm{C}$ under cool-white fluorescent lamps (16- or 18-hour photoperiod, 12 or $16 \mu \mathrm{mol} \cdot \mathrm{s}^{-1} \cdot \mathrm{m}^{-2}$ ) developed green areas that subsequently produced nodular structures. Nodular structures produced proembryonal structures that developed into mature somatic embryos when transferred to media containing either $\mathrm{GA}_{3}\left(0.1 \mathrm{mg} \cdot \mathrm{liter}^{-1}\right)$ plus activated charcoal $\left(2.0 \mathrm{~g} \cdot \mathrm{liter}^{-1}\right)$ or casein hydrolysate (200 mg.liter $\left.{ }^{-1}\right)$ plus IAA $\left(0.5 \mathrm{mg} \cdot\right.$ liter $\left.^{-1}\right)$. Somatic embryos converted into plantlets when transferred to embryo conversion medium. Chemical names used: 1 - $H$-indole-3-acetic acid (IAA); gibberellic acid $\left(\mathrm{GA}_{3}\right)$.
\end{abstract}

Babaco originated in the Ecuadorian Andean Highlands. The edible fruits are parthenocarpic and contain flavonoids and digestive enzymes similar to those in papaya. Babaco is dioecious; there are only distillate plants that are cross-incompatible with related species (Horovitz and Jimenez, 1967). Thus, improvement via conventional breeding is impossible. An alternative method to breeding for improved fruit crops involves the regeneration of somaclonal variants via somatic embryogenesis or organogenesis. Tissue culture regeneration may allow for the selection of new babaco types having pest resistance, cold hardiness, or enhanced fruit characteristics.

Papaya, a more commonly known Carica crop, has been successfully regenerated from callus derived from seedling stem (DeBruijne et al., 1974; Yie and Liaw, 1977), anthers (Litz and Conover, 1978; Tsay and Su, 1985), embryos (Phadnis et al., 1970), and ovules (Litz and Conover, 1982). Other Carica spp. that have been regenerated by somatic embryogenesis include C. stipulata (Litz and Conover, 1980) and C. candamarcencis (Jordan et al., 1982/83).

Ovules were chosen as explants based on availability and reports of successful regeneration in other crops. Crops that have been regenerated from callus cultures originating from unfertilized ovules include Citrus spp. (Kochba and Button, 1974; Mitra and Chaturvedi, 1972) and Cabernet-Sauvignon grape (Mullins and Srinivasan, 1976).

Babaco has been micropropagated in vitro from shoot tips (Cohen and Cooper, 1982) and axillary buds (Cossio, 1988); however, there have been no reports of regeneration from callus. Thus, the objective of this study was to regenerate babaco plants from ovular callus.

Received for publication 28 June 1990. Published as Miscellaneous Paper no. 1283 of the Delaware Agricultural Experiment Station. Mention of trade names in this publication does not imply endorsement by the Delaware Agricultural Experiment Station of products named, nor criticism of similar ones not named. This research was supported by funds provided by the Univ. of Delaware Office of International Development and the U.S. Agency for International Development. The cost of publishing this paper was defrayed in part by the payment of page charges. Under postal regulations, this paper therefore must be hereby marked advertisement solely to indicate this fact.

'Graduate student. Currently Assistant Director, AMDE Corp., P.O. Box 632, Ambato, Ecuador.

${ }^{2}$ Associate Professor.

\section{Materials and Methods}

Plant material. Babaco plants were grown in the Univ. of Delaware greenhouse. A 2-year-old plant was the stock plant during the 1st year, and was supplemented with new material provided by R. Litz for the 2 nd year. Plants were vegetatively propagated from lateral shoots. Flowers tagged at anthesis were labeled as day 1 for fruit age. Fruit were selected at stages of development ranging from 23 to 140 days after anthesis (DAA) and were 3 to $20 \mathrm{~cm}$ long.

Surface disinfection, refrigeration, and culture. Fruit were harvested from the greenhouse in the morning except for pretreated fruit that were collected the previous afternoon and refrigerated at $4 \mathrm{C}$ for $1,3,5$, or 15 days. Fruit were dipped in $95 \%$ ethanol and then placed in a solution of $20 \%$ household bleach ( $1.0 \%$ sodium hypochlorite) with $0.1 \%$ Tween 20 for 20 to $30 \mathrm{~min}$ with continuous agitation. Fruit were washed with three rinses of distilled, sterile water before culture. Surfacedisinfected fruit were dissected longitudinally along the fruit angles. Only uninjured ovules were cultured longitudinally on the medium surface for measurement and data collection. Calli were subculture every 5 to 6 weeks and were maintained for more than a year.

\section{Media}

Callus. Media used included the basal salts of Murashige and Skoog (1962) (half-or full-strength major salts) or White (1943) (modified to include MS chelated iron) and, unless stated otherwise, the following addenda (in $\mathrm{mg} \cdot \mathrm{liter}^{-1}$ ): pyridoxine $\mathrm{HCl}$, 0.5; thiamine $\mathrm{HCl}, 0.4$; myo -inositol, 1 ; nicotinic acid, 0.5 ; sucrose, 30,000 and washed Difco Bacto agar (Difco Laboratories, Detroit), 8000. Organic N sources included glutamine (GLU), 400; proline (PRO), 400; adenine sulfate (AdS), 40; or casein hydrolysatc $(\mathrm{CH}), 1,000$. Growth regulators used were $N$-(phenyl-methyl)- $1 H$ - -purin-6-amine (BA), 1-naphthaleneacetic acid (NAA), IAA, and 3,6-dichloro-2-methoxybenzoic acid (Dicamba), in various combinations and concentrations ranging from 0.25 to $2 \mathrm{mg} \cdot$ liter $^{-1}$ Medium $\mathrm{pH}$ was adjusted to 5.7 to 5.8 before autoclaving at $121 \mathrm{C}$ and $124 \mathrm{kPa}$ for $15 \mathrm{~min}$.

Abbreviations: DAA, days after anthesis. 
Media were dispensed into $100 \times 15 \mathrm{~mm}(20 \mathrm{ml})$ or $60 \times 15$ $\mathrm{mm}(10 \mathrm{ml})$ petri dishes.

Somatic embryo treatments. Immature somatic embryos were cultured for 1 to 2 days on semi-solid medium containing 2,3,5triiodobenzoic acid (TIBA) at 1 to $4 \mathrm{mg} \cdot \operatorname{liter}^{-1}$ or in liquid medium containing half-strength MS salts to eliminate recallusing.

Embryo conversion. Embryo conversion medium consisted of a modified babaco shoot-growth medium (Cossio, 1988) and contained full-strength MS salts and vitamins, a second complement of MS microelements, and the following addenda (in mg.liter ${ }^{-1}$ ); AdS, 80; CH, 500; sucrose, 30,000; BA, 0.1 and agar, 7000 . The $\mathrm{pH}$ was adjusted to 5.4 to 5.6 before autoclaving. Medium $(25 \mathrm{ml})$ was dispensed into $55 \times 70 \mathrm{~mm}$ jars. Converted embryos 3 to $4 \mathrm{~cm}$ long were transplanted into a proprietary peat-lite mix (Redi-Earth, W.R. Grace, Fogelsville, $\mathrm{Pa}$.) and placed in the greenhouse under intermittent mist (6 sec every $6 \mathrm{~min}$ ).

Environmental conditions. Cultures were placed either in darkness or under a 16-h photoperiod using cool-white fluorescent lamps $\left(50 \mu \mathrm{mol} \cdot \mathrm{s}^{-1} \cdot \mathrm{m}^{-2}\right)$. Light conditions for somatic embryo induction and development consisted of a 16- or 18-h photoperiod with light intensities of 12,16 , or $24 \mu \mathrm{mol} \cdot \mathrm{s}^{-1} \cdot \mathrm{m}^{-2}$. The air was at $23 \pm 2 \mathrm{C}$ and at ambient relative humidity.

Histological procedures. Tissues were fixed in FAA (formalin: acetic acid (30\%): ethanol, 1:1:10) for $48 \mathrm{~h}$, dehydrated through an ethanol series, and embedded in paraffin. Blocks were cut with a rotary microtome set at 12 to $15 \mu \mathrm{m}$, stained with safranin, and fast green and mounted with Permount (Berlyn and Miksche, 1976).

Statistical evaluation. Six to 20 ovules were cultured per petri dish depending on the size of ovules and container. Observations were made on the 1st day after culture and weekly thereafter. Data collected included percentage and area of ovules initiating callus and callus growth (area). Callus growth was calculated by multiplying two measurements: $D_{1}=$ diameter and $D_{2}=$ diameter perpendicular to $D_{1}$ (King and Morehart, 1988). There were two or three replications per treatment, depending on the availability of material. Experiments were set up in factorial combinations in a randomized design. Data were evaluated using an unbalanced analysis of variance. General linear models and least square means were calculated and stepwise comparisons made to determine significance when applicable.

\section{Results}

Explant condition. Babaco flowered in February and continued until November. Fruit of similar ages were similar in length irrespective of season. The number of ovules per fruit depended on fruit age, with 195 to 225 present during the first 2 months. Ovule length and overall size depended on the age of the fruit and location within the fruit. The larger ovules were located at the stylar end. Ovules in fruit $>90$ days old were commonly shrunken; however, some resembled mature Carica seeds. Many fruit that originated in the summer had abnormalities, such as rounded. shape, six sides, and green structures instead of ovules.

Normal fruit were pentagonal, with five lodes, and the ovules were located in two opposing rows per locule. Fruit 7 DAA contained young, normal ovules composed of a vascularized funiculus and an outer and inner integument surrounding the nucellus, except at the micropyle, with the nucellus enclosing a megaspore mother cell (observation not shown).

Callus origin. Callus appeared to have three origins from ovules: the inner and outer integuments (Fig. 1A) and an inner origin that may be nucellar (Fig. 1B) containing small and heavily stained cells.

\section{Callus initiation and growth}

Ovule size and age. Callus produced per ovule (60 to 90 DAA) after 6 weeks in culture appeared to be directly related to ovule length (Fig. 2) and age (data not shown). Longer and older ovules produced more callus.

Salt formation. Callus produced per ovule after 6 weeks was significantly larger on White's than on full-strength MS medium (Table 1). In a subsequent experiment, ovules cultured on halfstrength MS for 6 weeks had a larger mean callus area than either of the former treatments.

Light vs. dark. Two experiments were conducted to compare the effects of light and dark on callus initiation. Ovules from fruit of four ages refrigerated (45 and 51 DAA) or nonrefrigerated (66 and $70 \mathrm{DAA}$ ); or from refrigerated fruit of three ages $(110,115$, and 130 DAA) were cultured on MS medium supplemented with GLU. In expt. 1, regardless of age or refrigeration, ovules produced a greater amount of callus in darkness than in light after 28 days (Fig. 3). In expt. 2, a similar percentage of ovules produced callus and areas of callus were also similar after 15 days of culture either in light or darkness, but after 45 days of culture, ovules maintained in the light produced

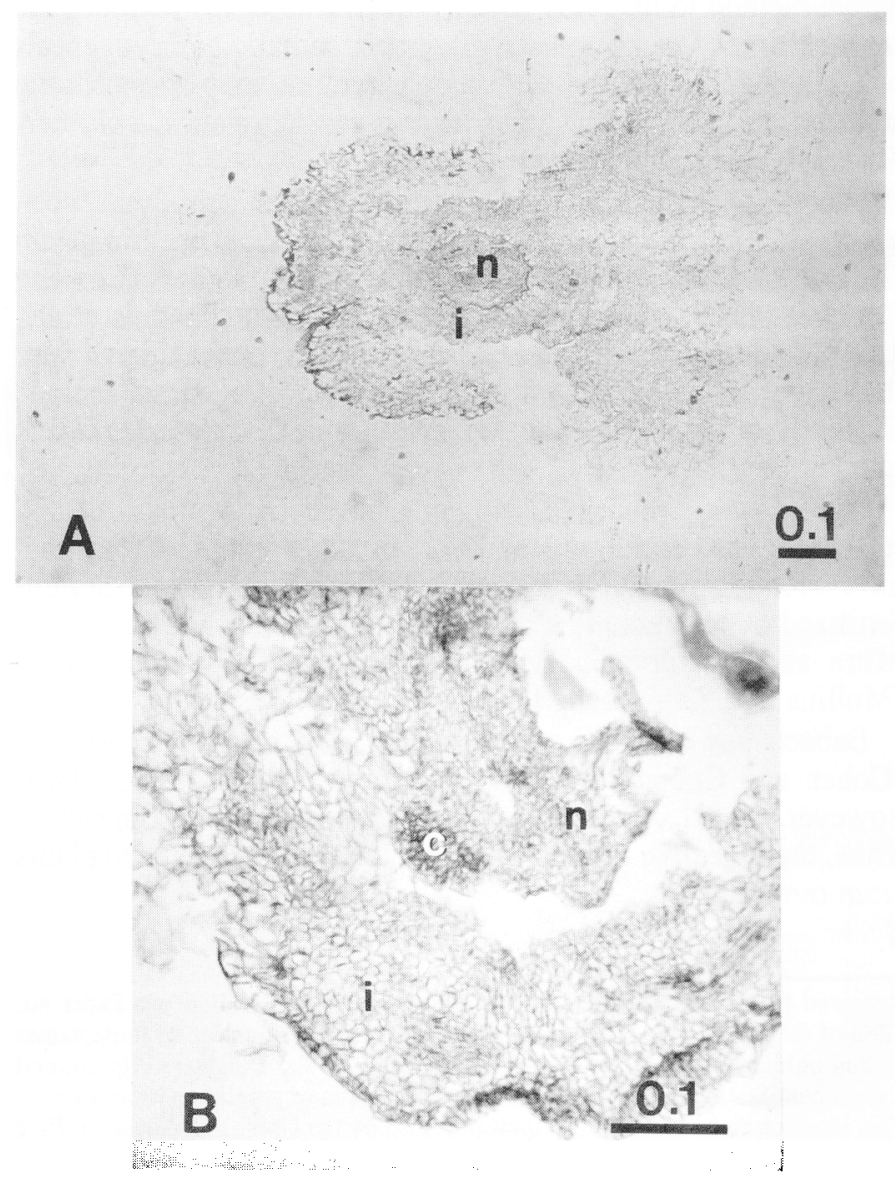

Fig. 1. Longitudinal sections of normal spring ovules (60 DAA) after 3 weeks in culture. (A) An ovule with callus that appears to have initiated from both the inner and outer integuments (i) and containing nucellus (n); and (B) an ovule with "nucellar" callus (c) containing small densely staining cells, integument (i), and nucellus (n) (bars $=\mathrm{mm})$. 


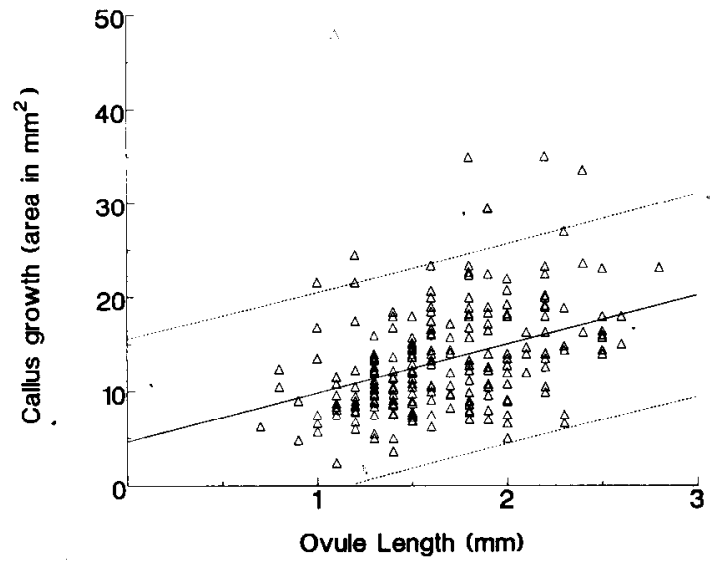

Fig. 2. Influence of ovule length on callus area produced after 6 weeks in culture (mean $\pm 5 \%$ confidence interval).

Table 1. Effect of medium formulation on babaco callus area after 6 weeks in culture.

\begin{tabular}{lcc}
\hline \hline Medium & & \\
\hline Expt. 1w & $\mathrm{n}^{\mathrm{y}}$ & $\begin{array}{c}\text { Callus area } \\
\left(\mathrm{mm}^{2}\right)\end{array}$ \\
White's & 20 & $11.4 \pm 1.32^{*}$ \\
Full-MS & 22 & $8.3 \pm 1.22$ \\
Expt. 2v & 48 & $14.0 \pm 2.17$ \\
Half-MS & 48
\end{tabular}

${ }^{\mathrm{z}}$ Murashige and Skoog, 1962, at full-strength and at half-strength major salts, and White's, 1943.

No. of petri dishes (10-12 ovules/dish).

${ }^{x}$ Mean \pm SE.

"Ovules from fruit 87-130 DAA.

${ }^{v}$ Ovules from fruit 90-140 DAA.

* Significant at $P=0.05$ by least square means.

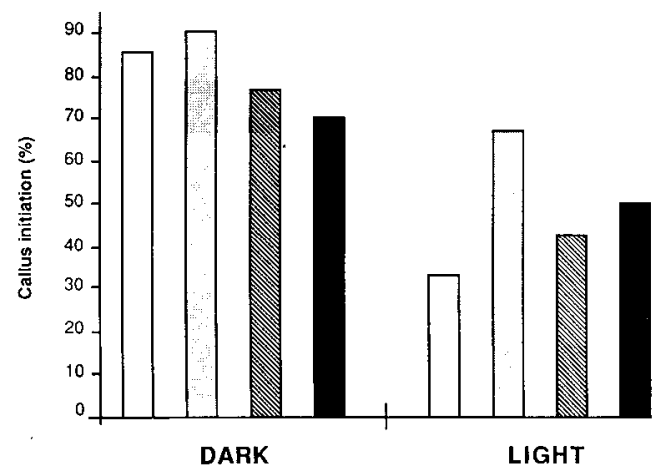

Fig. 3. Influence of illumination, refrigeration, and age on callus initiation from ovules from winter fruit. Ovules nonrefrigerated, $>60$ days ( $\square$ ); refrigerated $>60$ days (田); nonrefrigerated, $<60$ days $(\mathbb{\mathbb { N }})$; refrigerated, $<60$ days $(\square)$.

callus with a significantly greater frequency and larger area (Table 2). However, callus produced in the light was watery compared with callus produced in the dark, which was compact and had a more uniform surface. Subsequent experiments included darkness as a condition for callus initiation.

Refrigerated vs. fresh. Refrigerating the fruit before culture had a variable effect on ovular callus initiation. In an initial 6week-long experiment, significantly more callus was initiated from refrigerated ( 1 day) ovules $>60$ days old than from fresh ovules <60 days old (Table 3). A second experiment was set up using ovules from 130 DAA fruit refrigerated for 0,3 , or 5
Table 2. Influence of illumination on babaco callus initiation and growth.

\begin{tabular}{|c|c|c|c|c|c|}
\hline \multirow[b]{2}{*}{ Illumination } & \multirow[b]{2}{*}{$\mathrm{n}^{\mathrm{z}}$} & \multicolumn{2}{|c|}{$\begin{array}{l}\text { Ovules producing } \\
\text { callus }(\%)\end{array}$} & \multicolumn{2}{|c|}{ Callus area $\left(\mathrm{mm}^{2}\right)$} \\
\hline & & 15 days & 45 days & 15 days & 45 days \\
\hline Lighty $^{y}$ & 24 & 54 & $93^{*}$ & 7.95 & $19.85^{*}$ \\
\hline Dark & 24 & 40 & 67 & 7.73 & 8.21 \\
\hline
\end{tabular}

${ }^{2}$ No. of petri dishes (10-12 ovules/dish).

y $50 \mu \mathrm{mol} \cdot \mathrm{s}^{-1} \cdot \mathrm{m}^{-2}$.

*Significant at $P=0.05$ by general linear model.

Table 3. Effect of refrigeration on babaco callus initiation in culture.

\begin{tabular}{lccc}
\hline \hline Treatment & $\begin{array}{c}\text { Fruit age } \\
\text { (days) }\end{array}$ & $\mathrm{n}^{\mathbf{z}}$ & $\begin{array}{c}\text { Ovules initiating } \\
\text { callus }^{\mathrm{y}} \\
(\%)\end{array}$ \\
\hline Fresh & $>60$ & 13 & $71 \pm 0.55$ \\
& $<60$ & 10 & $43 \pm 0.07$ \\
Refrigerated $^{\mathrm{x}}$ & $>60$ & 11 & $85 \pm 0.05^{*}$ \\
& $<60$ & 11 & $52 \pm 0.09$ \\
\hline
\end{tabular}

${ }^{\mathrm{z}}$ No. of petri dishes (10 to 13 ovules/dish).

${ }^{y}$ Mean \pm SE of the mean.

${ }^{\mathrm{x}} 4 \mathrm{C}, 24 \mathrm{~h}$.

*Significantly different from fresh $<60$-day ovules at $P=0.05$ by least square means.

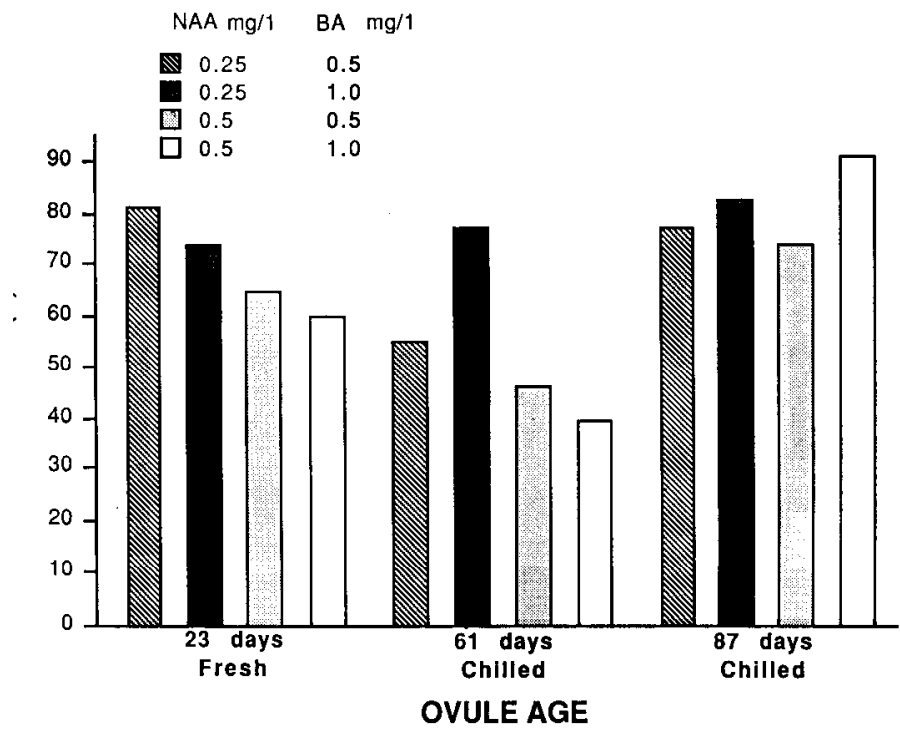

Fig. 4. Influence of NAA $\times$ BA concentration combinations, chilling, and ovule age on callus initiation.

days. Although callus initiation was highest (93\%) for 3 days of refrigeration, $86 \%$ of fresh ovules produced callus. In a third experiment, $79 \%$ to $88 \%$ of the ovules from 130 DAA fruit refrigerated for 15 days produced callus. Generally, refrigerated ovules produced callus earlier than fresh ovules.

\section{Growth regulators and organic nitrogen}

Growth regulators. Ovules from fruit 61 or 87 DAA pretreated by refrigeration (1 day), and from a 23 DAA fresh fruit were cultured on MS media containing a $2 \times 2 \times 2$ factorial of sucrose $(3 \%, 6 \%)$, BA $\left(0.5,1.0 \mathrm{mg} \cdot \mathrm{liter}^{-1}\right)$ and NAA $(0.25$, $0.5 \mathrm{mg} \cdot$ liter $\left.^{-1}\right)$. Sucrose concentration did not affect callus initiation. Callus initiation for all treatments was at least 39\% (Fig. 4). The most consistent callus initiation regardless of ovule age 
or refrigeration occurred on medium containing NAA at 0.25 $\mathrm{mg} \cdot$ liter $^{-1}$ and BA at $1.0 \mathrm{mg} \cdot \mathrm{liter}^{-1}$.

Organic nitrogen. Ovules from three fruit (110, 115, 130 DAA) were cultured on media containing half- or full-strength MS major salts supplemented with $\left(\mathrm{mg} \cdot \mathrm{liter}^{-1}\right)$ : NAA, 0.5; BA, 1.0, and the organic nitrogen sources GLU, 400; CH, 1000; AdS, 40; or PRO, 400. The percentage of ovules that produced callus was at least $67 \%$ with no significant difference among treatments (data not shown).

Growth regulators and organic nitrogen. Ovules from four fruit $(73,85,118,130$ DAA) were cultured on half-strength MS media containing (mg.liter ${ }^{-1}$ ): Dicamba, 2.0 and BA, 1.0; in combination with GLU, 400; $\mathrm{CH} 1000$; or AdS, 40; the control contained BA, 1.0; NAA, 0.5; and GLU, 400. Callus growth was evaluated after 45 days. Ovules 130 DAA produced the greatest amount of callus when cultured on medium with Dicamba, BA, and $\mathrm{CH}$ (Fig. 5). However, the greatest production of callus for ovules 73,85 , and 118 DAA was obtained with the control medium (Fig. 5).

Additional studies with NAA and BA in combination with GLU, $\mathrm{CH}, \mathrm{AdS}$, or PRO indicated that callus initiation and growth occurred equally well on all four $\mathrm{N}$ sources (data not shown). However, PRO and GLU are preferred due to earlier (PRO) and more consistent (GLU) callus initiation.

\section{Somatic embryogenesis}

Embryogenic callus initiation. Regenerative calli originated from 73 to 90 DAA (summer and fall fruit) ovules that had been refrigerated and cultured on semi-solid medium containing White's or half-strength MS salts, supplemented with MS vitamins, GLU, or PRO (400 mg.liter ${ }^{-1}$, NAA (0.25 to $\left.0.5 \mathrm{mg} \cdot \mathrm{liter}^{-1}\right)$, and BA (1 mg.liter $\left.{ }^{-1}\right)$ in light $\left(50 \mu \mathrm{mol} \cdot \mathrm{s}^{-1} \cdot \mathrm{m}^{-2}\right.$ with a $16-\mathrm{h}$ photoperiod) or darkness.

Embryogenic callus maintenance. Callus was maintained in light or darkness and subculture every 5 to 6 weeks. Callus maintenance medium contained NAA at $0.5 \mathrm{mg} \cdot$ liter $^{-1}$ and BA at $1.0 \mathrm{mg} \cdot$ liter $^{-1}$. During subsequent subcultures the growth regulators were removed from the medium as follows: subculture 1 (mg.liter $\left.{ }^{-1}\right)$ : 0 NAA, $1.0 \mathrm{BA}$; subculture 2: 0 NAA, 0.5 BA; subculture 3: 0 NAA, 0 BA subsequent three subcultures: no growth regulators. Half of the light-grown cultures became green when maintained without transferring them for 3 months. At this time, all light-grown and some dark-grown cultures were

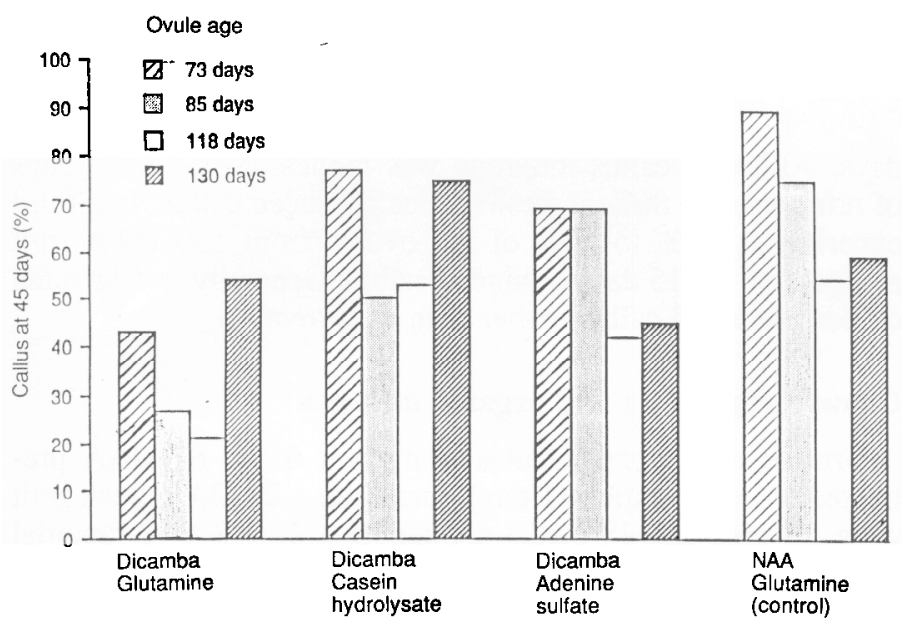

Fig. 5. Effect of organic $\mathrm{N}$ and auxins on callus growth on medium containing BA at $1 \mathrm{mg} \cdot$ liter $^{-1}$. placed under one of three light intensities $(12,16$, or 24 $\left.\mu \mathrm{mol} \cdot \mathrm{s}^{-1} \cdot \mathrm{m}^{-2}\right)$ and one of two photoperiods (16 or $\left.18 \mathrm{~h}\right)$. Callus placed under 12 or $16 \mu \mathrm{mol} \cdot \mathrm{s}^{-1} \cdot \mathrm{m}^{-2}$ grew and became green; callus under $24 \mu \mathrm{mol} \cdot \mathrm{s}^{-1} \cdot \mathrm{m}^{-2}$ did not grow. Photoperiod had no effect on callus growth or greening. Green calli were either friable or compact.

Nodular callus and somatic embryo initiation. Compact green callus was cultured on medium containing half-strength MS salts; GLU or PRO at $400 \mathrm{mg} \cdot \mathrm{liter}^{-1}$; sucrose at $3 \%, 6 \%$, or $9 \%$; and $\mathrm{BA}$ at $0,1,2$, or $3 \mathrm{mg} \cdot$ liter $^{-1}$. Callus initially maintained on medium containing $3 \%$ sucrose and subsequently onto media containing $3 \%$ or $6 \%$ sucrose and subsequently onto media containing $3 \%, 6 \%$, or $9 \%$ sucrose. After 4 months, the compact green calli became nodular (Fig. 6A). Anatomically, these nodules contained small densely staining cells that were actively dividing (Fig. 6B). Proembryonal structures developed when nodular green callus from media containing $3 \%$ or $6 \%$ sucrose was subculture onto media containing BA (1 to $3 \mathrm{mg} \cdot \mathrm{liter}^{-1}$ ) and then onto medium containing $3 \%$ sucrose and no growth regulators. Nodular green callus cultures were grown under 16or 18 -h photoperiods; only 18 -h cultures regenerated.

Somatic embryo development. Globular proembryonal structures turned green and developed leaf primordia when subcultured twice onto medium without growth regulators. Red pigments were always associated with the leaf primordia. The globular proembryonal structures failed to develop further and recallused.

To eliminate recallusing, globular proembryonal structures were cultured either onto semi-solid basal media with TIBA or in liquid half-strength MS medium. TIBA cultures produced a few embryos and many roots. Globular proembryonal structures cultured in liquid half-strength MS medium for 1 week developed into somatic embryos when subculture onto semi-solid medium containing (mg.liter ${ }^{-1}$ ): either sucrose, 60,000; GA , 0.1 and activated charcoal, 2000; or sucrose, 30,000; IAA, 0.5 and $\mathrm{CH}, 200$. Although more somatic embryos and roots re-
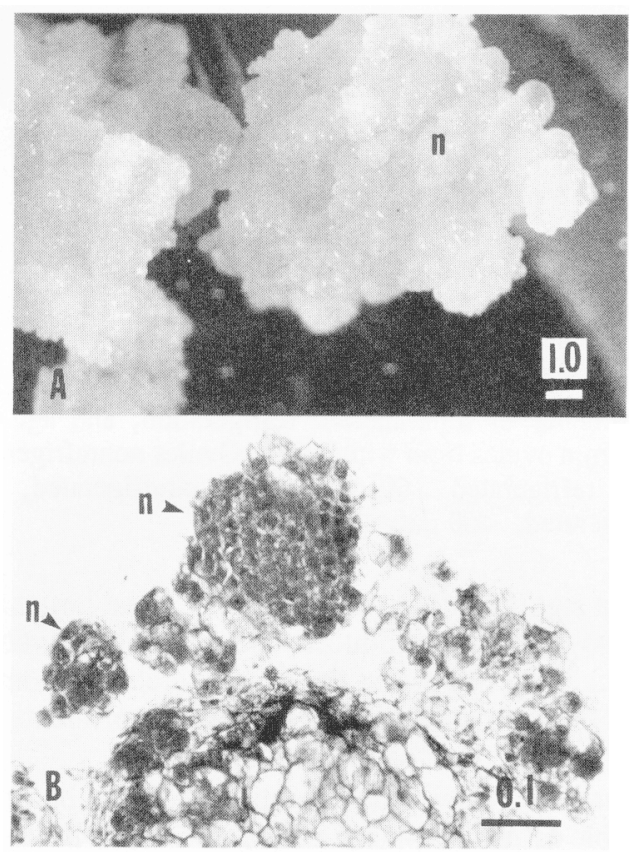

Fig. 6. Calli produced from habituated ovular callus. (A) Nodular (n) calli produced in the light from habituated callus; and (B) histological section of nodular calli containing small densely staining cells within the nodules $(\mathrm{n})($ bars $=\mathrm{mm})$. 
generated when cultured on medium with GA and charcoal (Table 4), more normal somatic embryos were produced on medium containing IAA $+\mathrm{CH}$. Anatomically normal somatic embryos were bipolar, with shoot and root initials, and developed from globular- to heart-shaped somatic embryos (Fig. 7A).

Somatic embryo conversion and micropropagation. Somatic embryos with well-developed cotyledons and roots (Fig.. 7B) were transferred to $55 \times 70 \mathrm{~mm}$ jars containing somatic embryo conversion medium. Six weeks after initiation, somatic embryos reached the three-leaf stage and had lanceolate leaves. Two 3$\mathrm{cm}$ plantlets were potted in Redi-Earth and placed in the greenhouse under mist. One plant rooted and grew.

\section{Discussion}

Although callus did not initiate uniformly over the surface of the ovules, callus growth was correlated with ovule length (Fig. 2 ). Larger ovules produced more callus than smaller ovules. This difference could be due to the larger surface area, or to differences in physiological development.

More callus initiated on White's than on full-strength MS salts. However, reduction of MS salts to half strength appeared to enhance callus initiation and growth similar to that on White's (Table 1). Callus initiation from hypocotyl sections of $C$. candamarcensis, when cultured on three different nutrient solutions, was similar (Jordan et al, 1982/83).

We found no reports of refrigeration as an ovule pretreatment; however, cold conditioning has been commonly used in anther culture (Rashid and Reinert, 1981). Generally, a greater percentage of babaco ovules produced callus, and produced callus earlier, when refrigerated at 4C. This low-temperature effect may be related to an increase in endogenous growth factors as has been reported with hazel seeds (Frankland and Wareing, $1966)$.

Generally, ovules cultured on medium containing the growth regulators NAA (0.5 mg.liter ${ }^{-1}$, and BA (1.0 mg.liter ${ }^{-1}$, produced more callus than those on medium containing Dicamba (2.0 mg.liter ${ }^{-1}$ ) and BA (1.0 mg.liter $\left.{ }^{-1}\right)$ (Fig. 5). Lower concentrations of NAA and BA may be better for callus initiation from younger than from older ovules (Fig. 4). The response to NAA and BA concentrations by different-aged ovules may be due to endogenous growth regulator concentrations. For other Carica spp., NAA and BA have been critical for the initiation of regenerative callus (Litz and Conover, 1980; Yie and Liaw, 1977).

Organic $\mathrm{N}$ has been found to be helpful in callus cultures of Carica spp. (Cossio, 1985; Litz and Conover, 1982) and other species, including Citrus sinensis and C. grandis (Rangan, 1982), and Vitis vinifera (Mullins and Srinivasan, 1976). In babaco, all sources of organic $\mathrm{N}$ studied supported callus initiation and growth. Babaco somatic embryo initiation, development and conversion all occurred in the presence of organic $\mathrm{N}$.

Table 4. Babaco somatic embryogenesis from nodular callus.

\begin{tabular}{|c|c|c|c|c|c|}
\hline \multirow{2}{*}{$\begin{array}{l}\text { Callus } \\
\text { line .. } \\
\end{array}$} & \multirow[b]{2}{*}{ Treatment $^{\mathbf{z}}$} & \multirow[b]{2}{*}{$\mathbf{n}^{\mathbf{y}}$} & \multicolumn{3}{|c|}{ Regeneration } \\
\hline & & & Proembryos & Embryos & Roots \\
\hline \multirow[t]{2}{*}{ 8-B1 } & $\mathrm{GA}_{3}+$ charcoal & 28 & 63 & 19 & 3 \\
\hline & $\mathrm{IAA}+\mathrm{CH}$ & 26 & 111 & 7 & 0 \\
\hline \multirow[t]{2}{*}{$6-70$} & $\mathrm{GA}_{3}+$ charcoal & 14 & 34 & 8 & 1 \\
\hline & $\mathrm{IAA}+\mathrm{CH}$ & 12 & 30. & 0 & 0 \\
\hline
\end{tabular}

${ }^{2}$ Amendments $\left(\mathrm{mg}^{-}\right.$liter $\left.{ }^{-1}\right): 0.1$ gibberellic acid $\left(\mathrm{GA}_{3}\right)+1000$ activated charcoal or 0.5 IAA +200 casein hydrolysate $(\mathrm{CH})$. yNo. of petri dishes.

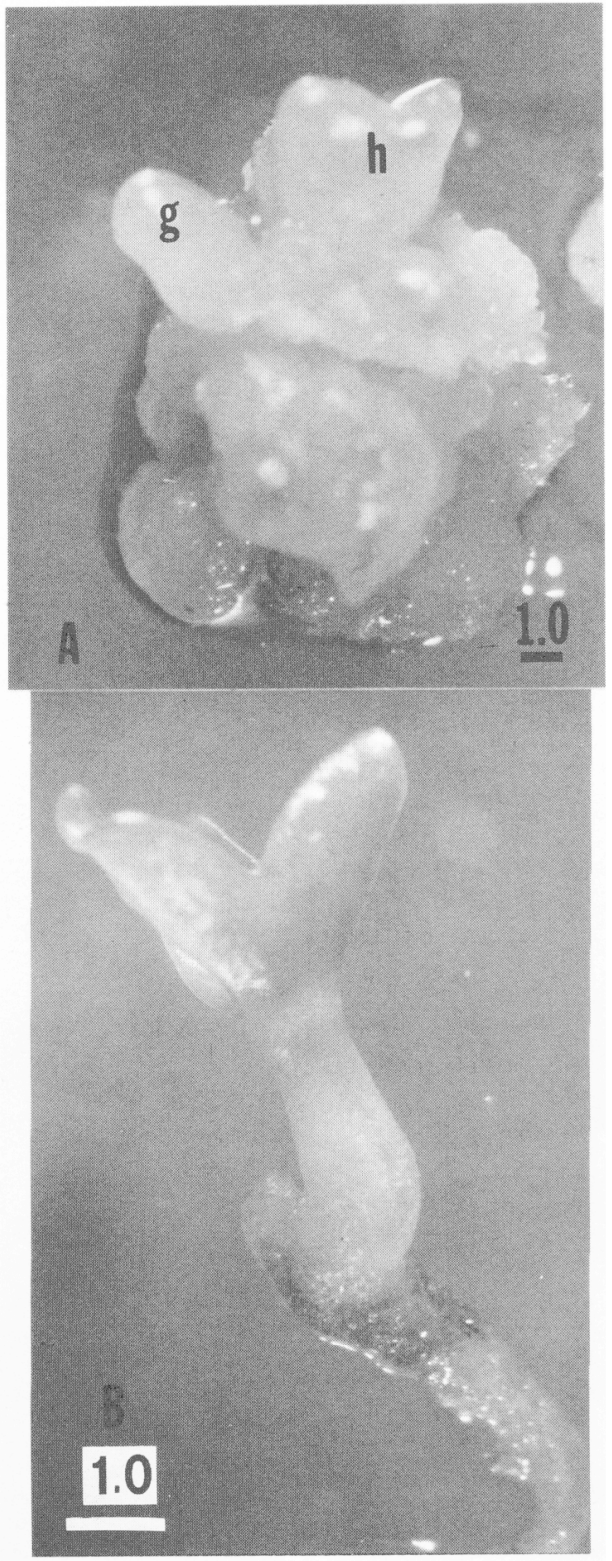

Fig. 7. Somatic embryos differentiated from nodular calli. (A) Globular- (g) and heart-shaped (h) somatic embryos developing on somatic embryo initiation medium; and (B) babaco embryo with developed cotyledons and root regenerated from ovular callus (bars $=\mathrm{mm})$.

Ovule age does not appear to be as critical in regeneration of navel orange (Moore, 1986) or papaya (Litz and Conover, 1982; Moore and Litz, 1984) as in babaco. Only callus originating from babaco ovules, 73 and 90 DAA, has been regenerative.

Babaco regeneration appears to depend on light intensity and photoperiod. Whereas light intensity and photoperiod were not critical for callus initiation, a light intensity of 12 to 16 $\mu \mathrm{mol} \cdot \mathrm{s}^{-1} \cdot \mathrm{m}^{-2}$ during an $18 \mathrm{~h}$ photoperiod was necessary for the initiation and development of somatic embryos from callus. Although papaya ovular cultures grew with a 16-h photoperiod (Litz, 1986), C. candamarcensis regenerated with an 18-h photoperiod (Jordan et al., 1982/83).

Green calli developed nodular sectors having embryogenic potential. This result is in contrast to Norway spruce callus cultures where abundant immature embryos were produced from white, translucent, mucilaginous calli (Becwar et al., 1987). 
Table 5. Regeneration sequence of babaco from ovules.

\begin{tabular}{|c|c|c|c|}
\hline \multirow{2}{*}{$\begin{array}{l}\begin{array}{l}\text { Regeneration } \\
\text { sequence }\end{array} \\
\text { Callus initiation }\end{array}$} & \multicolumn{2}{|c|}{$\begin{array}{c}\text { Special addenda } \\
\left(\mathrm{mg} \cdot \text { liter }^{-1}\right)\end{array}$} & \multirow{2}{*}{$\frac{\text { Subculture }}{1}$} \\
\hline & NAA & 0.5 & \\
\hline & $\mathrm{BA}$ & 1.0 & \\
\hline & GLU or PRO & 400 & \\
\hline \multirow[t]{9}{*}{ Callus habituation } & NAA & 0 & 2 \\
\hline & & 1.0 & \\
\hline & GLU or PRO & 400 & \\
\hline & NAA & 0 & 3 \\
\hline & & 0.5 & \\
\hline & GLU or PRO & 400 & \\
\hline & NAA & 0 & 4 \\
\hline & & 0 & \\
\hline & GLU or PRO & 400 & \\
\hline \multicolumn{4}{|l|}{ Green callus } \\
\hline initiation & \multicolumn{2}{|c|}{$\begin{array}{l}\text { No subculture } 3 \text { months } \\
\quad \text { (under light) }\end{array}$} & \\
\hline \multicolumn{4}{|l|}{ Nodular callus } \\
\hline initiation & $\mathrm{BA}$ & $1,2,3$ & 5 \\
\hline & Sucrose & $\begin{array}{c}30,000 \text { or } \\
60,000\end{array}$ & \\
\hline & GLU or PRO & 400 & \\
\hline \multirow{4}{*}{$\begin{array}{l}\text { Somatic embryo } \\
\text { initiation }\end{array}$} & & & \\
\hline & BA & 0 & 6 \\
\hline & Sucrose & 30,000 & \\
\hline & GLU or PRO & 400 & \\
\hline \multirow{6}{*}{$\begin{array}{c}\text { Somatic embryo } \\
\text { development }\end{array}$} & & & \\
\hline & $\mathrm{GA}_{3}$ & 0.1 & 7 \\
\hline & Charcoal & 2,000 & \\
\hline & & & \\
\hline & IAA & 0.5 & \\
\hline & $\mathrm{CH}$ & 200 & \\
\hline \multicolumn{4}{|l|}{ Embryo } \\
\hline \multirow[t]{3}{*}{ conversion } & $\mathrm{BA}$ & 0.5 & 8 \\
\hline & $\mathrm{CH}$ & 500 & \\
\hline & AdS & 80 & \\
\hline
\end{tabular}

${ }^{2}$ For further media details see Materials and Methods.

Several factors are known to modify the initiation and developmental pattern of somatic embryos in vitro, e.g., sucrose concentration, organic $\mathrm{N}$, growth regulator levels, and culture conditions (Ammirato, 1983). The addition of sucrose after a period of starvation appears to be one of the factors involved in the onset of differentiation in babaco cultures. Babaco somatic embryos have been recovered from calli maintained without subculturing for 3 months and then subculture on medium containing $3 \%$ or $6 \%$ but not $9 \%$ sucrose. Sucrose starvation also has been shown to be important in citrus (Kochba et al., 1982). In addition, habituated calli from various citrus clones maintained for long periods in culture had better growth and somatic embryo development when cultured on $5 \%$ to $6 \%$ sucrose than on medium containing $>10 \%$ sucrose, where a gradual decline in embryogenesis occurred (Kochba and Button, 1974).

Nodular callus of babaco cultured on medium containing either activated charcoal and $\mathrm{GA}_{3}$ or IAA and $\mathrm{CH}$ produced proembryos that developed further into somatic embryos. Although these compounds have been associated with enhanced somatic embryo development (Litz and Conover, 1980; Jordan et al., 1982/83; Trolinder and Goodin, 1988) in the present study, a greater percentage of somatic embryos were normal when grown in the presence of IAA plus $\mathrm{CH}$.

A scheme for the recovery of babaco plants from ovular callus is summarized in Table 5. However, improvement of the efficiency for producing regenerative callus and converting somatic embryos is essential if this procedure is to be used for recovery of somaclonal variants.

\section{Literature Cited}

Ammirato, P.V. 1983. Embryogenesis, p. 82-123. In: D.A. Evans, W.R. Sharp, P.V. Ammirato, and Y. Yamada (eds.). Handbook of plant cell culture, vol. 1. Macmillan, New York.

Becwar, M.R., T.L. Noland, and S.R. Warm. 1987. A method for quantification of the level of somatic embryogenesis among Norway spruce callus lines. Plant Cell Rpt. 6:35-38.

Berlyn, G.P. and J.P. Miksche. 1976. Botanical microtechnique and cytochemistry. The Iowa State Univ. Press, Ames.

Cohen, D. and P.A. Cooper. 1982. Micropropagation of babaco. A Carica hybrid from Ecuador, p. 743-744. In: A. Fujiwara (ed.). Plant tissue culture 1982. 5th Intl. Congr. Plant Tissue and Cell Culture. Jpn. Assn. Plant Tissue Culture, Tokyo. Cossio, F. 1985. Babaco, frutto prossimo future? Informatore Agrario. 41:13-67. Cossio, F. 1988. I1 babaco. Edagricole, Bologna, Italy.

DeBruijne, E., E. DeLanghe, and R. Van Rijck. 1974. Actions of hormones and embryoid formation in callus cultures of Carica papaya. Rijksuniversiteit te Gent (Belgium) 39637-646.

Frankland, B. and P.G. Wareing. 1966. Hormonal regulation of seed dormancy in hazel (Corylus avellana L.) and beech (Fagus sylvatica L.). J. Expt. Bot. 17:596611.

Horovitz, S. and H. Jimenez. 1967. Cruzamientos interespecificos e intergenericos en caricaceas y sus implicaciones fitotencnicas. Agron. Trop. (Venezuela) 17:323343.

Jordan, M., I. Cortes, and G. Montenegro. 1982/83. Regeneration of plantlets by embryogenesis from callus cultures of Carica candamarcencis. Plant Sci. Let. 28:321-326

King, S.M. and A.L. Morehart. 1988. Correlation of callus weight to volume of two woody species. HortScience 23:219.

Kochba, J. and J. Button. 1974. The stimulation of embryogenesis and embryoid development in habituated ovular callus from the 'Shamouti' orange (Citrus sinensis) as affected by tissue age and sucrose concentration. Z. Pflanzenphysiol. 73:415-421

Kochba, J., P. Spiegel-Roy, H. Neumann, and S. Saad. 1982. Effect of carbohydrates on somatic embryogenesis in subculture nucellar callus of Citrus cultivars. Z. Pflanzenphysiol. 105:359-368.

Litz, R.E. and R.A. Conover. 1978. Recent advances in papaya tissue culture. Proc. Fla. State Hort. Soc. 91:180-182.

Litz, R.E. and R.A. Conover. 1980. Somatic embryogenesis in cell cultures ofCarica stipulata. HortScience 15:733-734.

Litz, R.E. and R.A. Conover. 1982. In vitro somatic embryogenesis and plant regeneration from Carica papaya L. ovular callus. Plant Sci. Let. 26:153-158.

Litz, R.E. 1986. Effect of osmotic stress on somatic embryogenesis in Carica suspension cultures. J. Amer. Soc. Hort. Sci. 111:969-972.

Mitra, G.C. and H.C. Chaturvedi. 1972. Embryoids and complete plants from unpollinated ovaries and from ovules of in vivo- grown emasculated flower buds of Citrus spp. Bul. Torrey Bot. Club 99:184-189.

Moore, G.A. 1986. Somatic embryogenesis in citrus, p. 47. In: H.M. Poltronieri (ed.). Biotechnology in the Americas II: Applications in tropical agriculture. Jimenez and Tanzi, San Jose, Costa Rica.

Moore, G.A. and R.E. Litz. 1984. Biochemical markers for Carica papaya, C. cauliflora, and plants from somatic embryos of their hybrid. J. Amer. Soc. Hort. Sci. 109:213-218

Mullins, M.G. and C. Srinivasan. 1976. Somatic embryos and plantlets from an ancient clone of the grapevine (cv. Cabernet Sauvignon) by apomixis in vitro. J. Expt. Bot. 27:1022-1030.

Murashige, T. and F. Skoog. 1962. A revised medium for rapid growth and bio assays with tobacco tissue cultures. Physiol Plantarum 15:473-497.

Phadnis, N.A., N.D. Budrukkar, and S.N. Kaulgud. 1970. Embryo culture technique in papaya (Carica papaya L.). Poona Agr. College Mag. 60: 101-104.

Rangan, T.S. 1982. Ovary, ovule, and nucellus culture, p. 105-129. In: B.M. Johri (ed.). Experimental embryology of vascular plants. Springer-Verlag, New York.

Rashid, A. and J. Reinert. 1981. In vitro differentiation of embryogenic pollen, control by cold treatment and embryo formation in ab initio pollen cultures of Nicotiana tabacum var. Badischer Burley. Protoplasm 109:285-294.

Trolinder, N.L. and J.R. Goodin. 1988. Somatic embryogenesis in cotton (Gossypium) II. Requirements for embryo development and plant regeneration. Plant Cell Tissue Organ Culture 12:43-53.

Tsay, H.S. and C.Y. Su. 1985. Anther culture of papaya (Carica papaya L.). Plant Cell Rpt. 4:28-30.

White, P.R. 1943. A handbook of plant tissue culture. Jacques Cattel Press, Lancaster, Pa.

Yie, S.-T. and S.I. Liaw. 1977. Plant regeneration from shoot tips and callus of papaya. In Vitro 9:564-568. 